\title{
Sejtszintü képalkotás a retina in vivo vizsgálatában: jelen és jövő
}

\author{
Végh András dr. ${ }^{1,2}$ - Magda Dániel Péter ${ }^{1}$ - Kilin Ferenc ${ }^{1}$ - Csorba Anita dr. ${ }^{2}$ \\ Resch Mikós dr. ${ }^{2}$ - Nagy Zoltán Zsolt dr. ${ }^{2}$. Szabó Arnold dr. ${ }^{1}$
}

${ }^{1}$ Semmelweis Egyetem, Általános Orvostudományi Kar, Anatómiai, Szövet- és Fejlődéstani Intézet, Budapest ${ }^{2}$ Semmelweis Egyetem, Általános Orvostudományi Kar, Szemészeti Klinika, Budapest

\begin{abstract}
A látószerv különböző betegségei, valamint egyes szisztémás megbetegedések részben vagy kifejezetten az ideghártya károsodásával járnak. A patológia segítségével ma már tudjuk, hogy ezek a betegségek a retina mely rétegének vagy rétegeinek elváltozásait okozzák: míg az időskori maculadegeneratio a külső retinában található fotoreceptorokat érinti kifejezetten a fovea centralis területén, addig a glaucoma a belső retina ganglionsejtjeinek pusztulásával, valamint e sejtek opticusrostjainak károsodásával jár a stratum ganglionaréban és a stratum neurofibrarumban. Az emberi retina sejtjei azonban egyelőre nem maradéktalanul karakterizáltak, az egyes sejttípusok számát csak becsülni tudjuk, így nem írhatók le az egyes sejtszintű elváltozások sem kellő pontossággal. A szövettani feldolgozás és vizsgálat megfelelő részletességgel tájékoztat a diagnózisról és az elváltozás súlyosságáról, értelemszerúen azonban ez a módszer in vivo nem használható a mindennapi klinikai gyakorlatban. A sejtszintű elváltozások ismerete az egyes kórképekben felvetette és szükségessé tette olyan in vivo, a klinikumban is alkalmazható vizsgálómódszerek kifejlesztését, amelyek lehetőséget nyújtanak a retina neurális és egyéb sejtjeinek celluláris és szubcelluláris szintű vizsgálatára, ideértve a vér alakos elemeit is, amelyek egészséges vagy neovascularis eredetü erekben áramlanak. A jelenleg is használt klinikai vizsgálatok mellett ezek a képalkotó módszerek segítségül szolgálhatnak a diagnózis megerősítésében vagy elvetésében, emellett az elváltozás súlyosságának megítélésében, valamint a progresszió vagy remisszió monitorozásában.

Orv Hetil. $2021 ; 162(22): 851-860$.
\end{abstract}

Kulcsszavak: retina, optikaikoherencia-tomográfia (OCT), fluoreszcencia-életidős képalkotó oftalmoszkópia (FLIO), adaptív optika, kétfoton-oftalmoszkópia

\section{In vivo cellular imaging of the retina: present and future}

Diseases of the visual system as well as many systemic illnesses are usually associated with retinal damage. With the help of pathology, we can clearly identify the affected layer(s): while age-related macular degeneration mostly damages the photoreceptors in the outer retina at the central fovea, glaucoma promotes ganglion cell death in the ganglion cell layer and damages respective neural fibers. However, the diverse cell types of the human retina have not been fully characterized yet, thus in most cases our knowledge on cellular pathologies is not precise enough. While histopathological preparation and examination of the retinal tissue provide more detailed information about the diagnosis and the severity of the condition, unfortunately, it cannot be used in vivo in everyday clinical practice. Our understanding of the cellular changes in different diseases has revealed a need for new everyday clinical examination methods that can be used in vivo to asses cellular and subcellular changes in neural and other cells of the retina, such as blood cells flowing in healthy vessels or in vessels of neovascular origin. In addition to the currently used clinical examination methods, these imaging methods could help confirm or dismiss diagnoses, assess the severity of a condition, and monitor disease progression or remission.

Keywords: retina, optical coherence tomography (OCT), fluorescence lifetime imaging ophthalmoscopy (FLIO), adaptive optics, two-photon ophthalmoscopy

Végh A, Magda DP, Kilin F, Csorba A, Resch M, Nagy ZZs, Szabó A. [ In vivo cellular imaging of the retina: present and future]. Orv Hetil. 2021; 162(22): 851-860.

(Beérkezett: 2020. november 3.; elfogadva: 2020. december 4.) 


\section{Rövidítések}

AGE = (advanced glycation end product) késői glikációs végtermék; $\mathrm{AMD}=$ (age-related macular degeneration $)$ időskori maculadegeneratio; $\mathrm{AO}=$ adaptív optika CGL $=$ corpus geniculatum laterale; EDI = (enhanced-depth imaging) kiterjesztett mélységi képalkotás; FAD = flavin-adenin-dinukleotid; $\mathrm{FAF}=$ fundus-autofluoreszcencia; FLAG $=$ fluoreszcens angiográfia; FLIO (fluorescence lifetime imaging ophthalmoscopy) fluoreszcencia-életidős képalkotó oftalmoszkópia; FMN = flavin-mononukleotid; FRET $=($ Förster resonance energy transfer) Förster-típusú energiatranszfer; GA = geografikus atrophia; GABA $=$ (gamma-butyric acid $)$ gamma-aminovajsav; GCC = (ganglion cell complex) ganglionsejtkomplex; GCL $=$ (ganglion cell layer) ganglionsejtréteg; ICGA = (indocyanine green angiography) indocianinzöld-angiográfia; ILM = (inner limiting membrane) belső határhártya; INL = (inner nuclear layer $)$ belsô magvas réteg; IPL = (inner plexiform layer $)$ belső szinaptikus réteg; IPM = (interphotoreceptor matrix) interfotoreceptor-mátrix; IR = (infrared) infravörös; IS = (inner segment) beltag; MIR $=($ mid-infrared $)$ középinfravörös; $\mathrm{MP}=$ macularis pigment; $\mathrm{NAD}(\mathrm{P}) \mathrm{H}=$ nikotinamid-adenin-dinukleotid-foszfát; NFL $=$ (nerve fibre layer) opticusrostok rétege; NIR = (near infrared) közeli infravörös; OCT $=$ (optical coherence tomography) optikaikoherencia-tomográfia; OCTA = OCTangiográfia; OLM = (outer limiting membrane) külső határhártya; $\mathrm{ONL}=$ (outer nuclear layer) külső magvas réteg; OPL $=($ outer plexiform layer $)$ külső szinaptikus réteg; $\mathrm{OS}=$ (outer segment) kültag; $\mathrm{PKC}=$ proteinkináz $\mathrm{C} ; \mathrm{ROS}=$ reaktívoxigénszármazékok; $\mathrm{RPE}=($ retinal pigment epithelium $)$ retinalis pigmenthám; SLO = (scanning laser ophthalmoscopy) pásztázó lézeroftalmoszkópia; TPE = (two-photon excitation) kétfotonexcitáció; TPF = (two-photon fluorescence) kétfoton-fluoreszcencia

\section{Az ép retina mikroszkópos anatómiája}

Az ideghártya (tunica nervosa) makroszkóposan két részre osztható. Egyik része az ora serrata elé esik, melyet pars caeca retinae-nak nevezünk, és a látás folyamatában nem vesz részt; a másik része az ora serrata mögött helyezkedik el, ez a pars optica retinae, amely fotoszenzitív és transzdukciós elemeket tartalmaz, tehát részt vesz az ingerület kialakításában, továbbításában, valamint feldolgozásában. A retina a szemserlegből (calyx opticus) fejlődik, amely fejlődéstanilag a köztiagy (diencephalonhólyag) származéka, tehát valójában a központi idegrendszer része. Mindezekből adódik az a megállapítás is, hogy a látóideg (nervus opticus, II. agyideg) valójában nem agyideg, hanem egy központi idegrendszeri pályának felel meg. Az egykori szemserleg külső rétegéből a pigmenthám (stratum pigmentosum) fejlődik; a belső réteg sorsa eltér a retina makroszkópos részein: a pars caeca területén nem differenciálódik tovább, és megmarad egyrétegú hámként; a pars optica területén pedig további kilenc réteg alakul ki belőle, amelyek jellegzetes sejtes elemeket tartalmaznak. A szemserleg két rétege közötti űr (ventriculus opticus), amely morfofunkcionálisan a harmadik agykamra részének felel meg, virtuális résként marad vissza. Ez utóbbi jelentősége, hogy az egykori két réteg csak az ora serrata és a látóidegfő közelében rögzített egymáshoz, ezért a hátsó pólus felé lehetőség nyílik arra, hogy a pigmentepithel és a neuralis retina elváljanak egymástól, ezáltal jellegzetes klinikai képet és sürgős kezelést igénylő állapotot kialakítva. A retinát agyszöveti eredete miatt a pia maternek megfelelő chorioidea (tunica vasculosa seu uvea) és a dura maternek megfeleló sclera (tunica fibrosa) burkolja. Az ideghártya fényérzékeny részének felépítésében idegés gliasejtek, valamint az emberi szervezetben kizárólag itt megtalálható pigmenthámsejtek vesznek részt. Az idegsejtek közé a fotoreceptorok, a bipoláris és a ganglionsejtek tartoznak, melyek a vertikális neuronrendszert alkotják; valamint a horizontális és amakrin sejtek, amelyek a horizontális neuronrendszer felépítésében vesznek részt. A vertikális neuronrendszer a fényinger érzékelésében és az ingerület továbbításában, valamint feldolgozásában vesz részt, a horizontális neuronrendszer a retinalis jelfeldolgozásban játszik szerepet serkentő és gátló asszociációs idegsejtek segítségével. A támasztósejtek közül a legjellemzőbbek a Müller-sejtek, amelyek a retina vázát alkotó radiális gliasejtek. A Müller-sejtek a külső, valamint a belső határhártya (membrana limitans externa et interna) felépítésében játszanak szerepet nyúlványaik segítségével, melyek között sejtkapcsoló struktúrákat (zonula adherens) találunk. A Müller-sejteken kívül astrocyta- és microgliasejteket is találunk az ideghártyában.

A jelen leírásban a pars optica retinae tíz rétegét scleralis irány felól vitrealis irányba (kívülról befelé) haladva tárgyaljuk. Ez az irány megegyezik az ingerület haladási irányával a látókéreg felé, a feljebb tárgyalt fejlődéstani okok miatt azonban ellentétes a beérkező fény haladási irányával (inverz szem) (l-3.ábra) $[1,2]$.

A sclera irányából a legelső réteg a pigmenthám rétege (latin: stratum pigmentosum, angol: retinal pigment epithelium, RPE), amely a Bruch-membrán és a fotoreceptorok kültagjai között helyezkedik el. A polarizált sejtek között szoros sejtkapcsoló struktúrákat (tight junction) találunk. E szoros kapcsolatok hozzák létre a külső vér-retina gátat, védve az ideghártya igen érzékeny szövetét a kémiai és celluláris noxáktól, valamint immunprivilegizált szervvé téve azt. A sejtek szelektív tápanyag- és víztranszportot folytatnak a chorioidea felól, és ezáltal biztosítják saját maguk és a fotoreceptorok (érmentes külső retina) táplálását, valamint fenntartják a belsőbb rétegek vízháztartásának egyensúlyát. A pigmentepithel sejtjei nyúlványaikkal behatolnak a fotoreceptorok kültagjai közé, ezáltal fényzáró réteget hoznak létre, és védik az érzékhámsejteket a túlzott fényexpozíciótól; valamint fagocitálják a csapok és pálcikák elhasználódott apicalis darabjait. Emellett elvégzik a retinál transzportját és reizomerizációját, támogatva a fotoreceptorok metabolikus ciklusát. Termelik ezen túl az interfotoreceptor-mátrixot (IPM), amely a korábbi szemserleg két rétegét egymáshoz rögzíti, megakadályozva a retinaleválás (ablatio retinae) spontán kialakulását. A következő réteg (stratum neuroepitheliale seu coni et bacilli, outer 

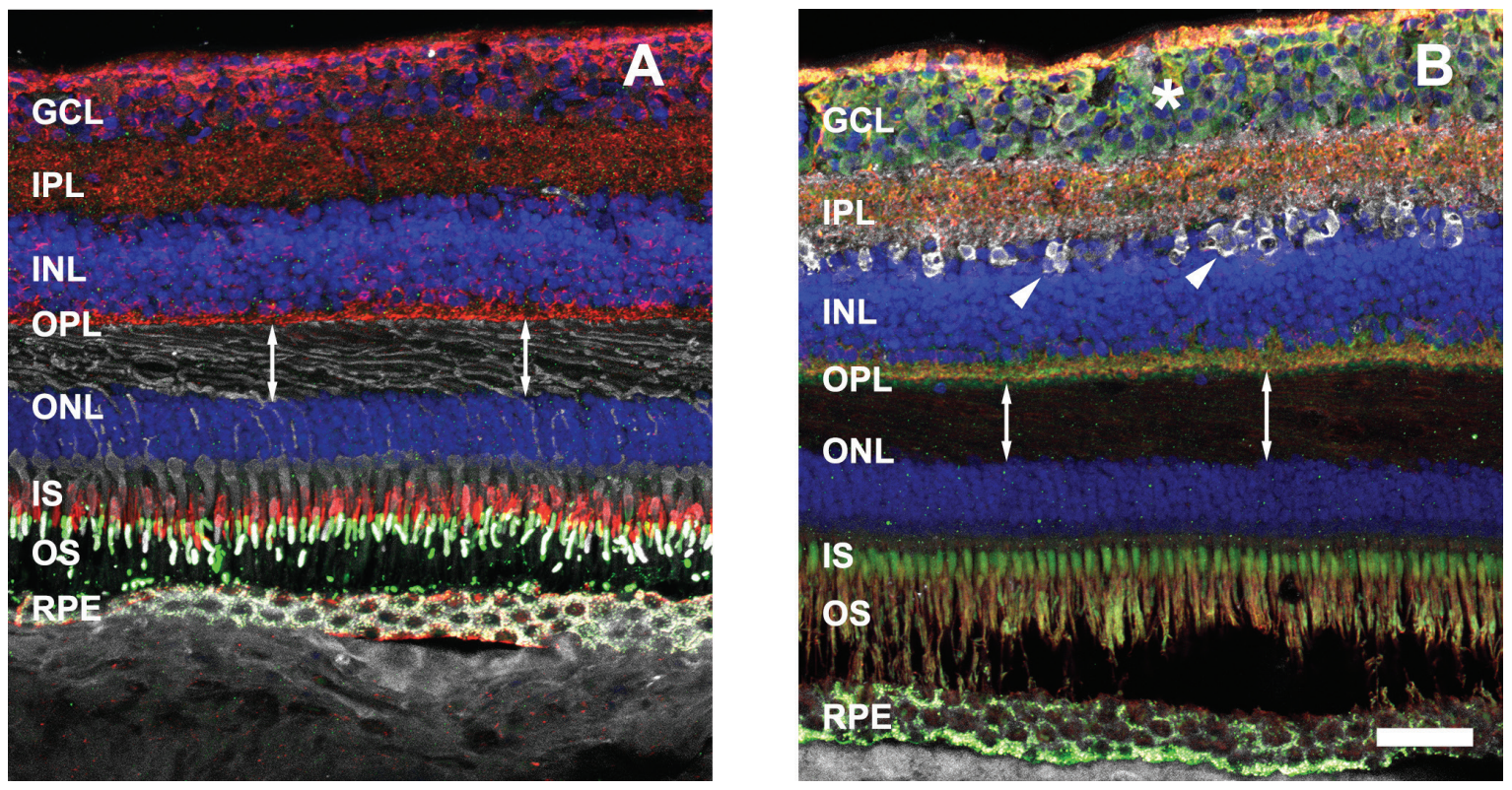

1. ábra

Egészséges felnőtt emberi centrális retina konfokális mikroszkópos felvételei. A) A zöld- és vörösérzékeny csapkültagok (anti-M/L-opsin antitest, Merck \#AB5405) zöld, a mitokondriumok (anti-MTCO ${ }_{2}$ antitest, Thermo Fisher Scientific \# MA5-12017) vörös, a csapok sejtjei szürke (anti-Arrestin 3 antitest, Novus Biologicals \#NBPI-37003) színben, a sejtmagok kék (DAPI) színben látszanak. B) A csillag zölden festett ganglionsejteket (anti-RBPMS-antitest, PhosphoSolutions \#1832-RBPMS) jelöl. A nyílhegyek szürkén festett amakrin sejtekre (antikalretinin-antitest, Merck \#MAB1568) mutatnak a stratum plexiforme internumban. A neurofilamentumok (anti-SMI32-anitest, Merck \#NE1023) vörös színben, a sejtmagok kék színben (DAPI) látszanak. A kettoós nyilak mindkét felvételen a csapok belső nyúlványait tartalmazó Henle-réteget mutatják a stratum plexiforme externumban. A lépték $50 \mu \mathrm{m}$. A munkacsoport korábban nem publikált felvételei

DAPI = 4',6-diamidino-2-fenilindol, egy fluoreszkáló folt; GCL = ganglionsejtréteg; INL = belső magvas réteg; IPL = belső szinaptikus réteg; IS = beltag; $\mathrm{ONL}=$ külső magvas réteg; $\mathrm{OPL}$ = külső szinaptikus réteg; $\mathrm{OS}$ = kültag; $\mathrm{RPE}=$ retinalis pigmenthám

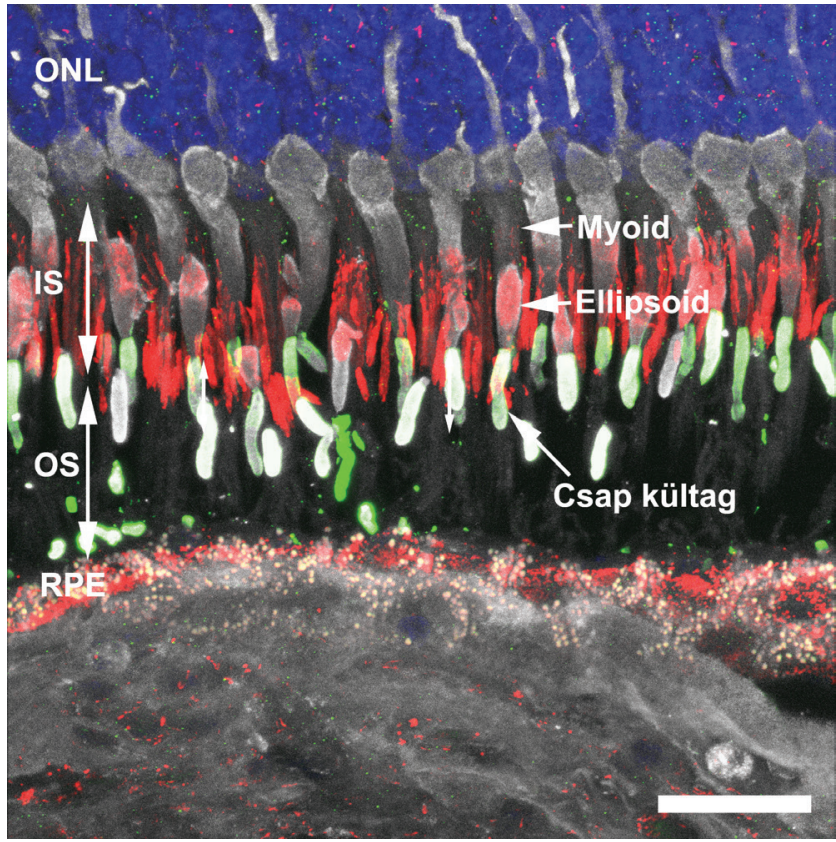

2. ábra
Egészséges felnőtt emberi centrális külső retina fotoreceptorainak konfokális mikroszkópos felvétele. A zöld- és vörösérzékeny csapkültagok (anti-M/L-opsin) zöld, a fotoreceptorok mitokondriumokat tartalmazó ellipszoidjai (anti- $\mathrm{MTCO}_{2}$ ) vörös, a csapok sejtjei szürke (antiarresztin-3) színben, a sejtmagok kék (DAPI) színben látszanak. A lépték $25 \mu \mathrm{m}$. A munkacsoport korábban nem publikált felvétele

DAPI = 4',6-diamidino-2-fenilindol, egy fluoreszkáló folt; IS = beltag; $\mathrm{ONL}=$ külsó magvas réteg; $\mathrm{OS}=$ kültag; $\mathrm{RPE}=$ retinalis pigmenthám

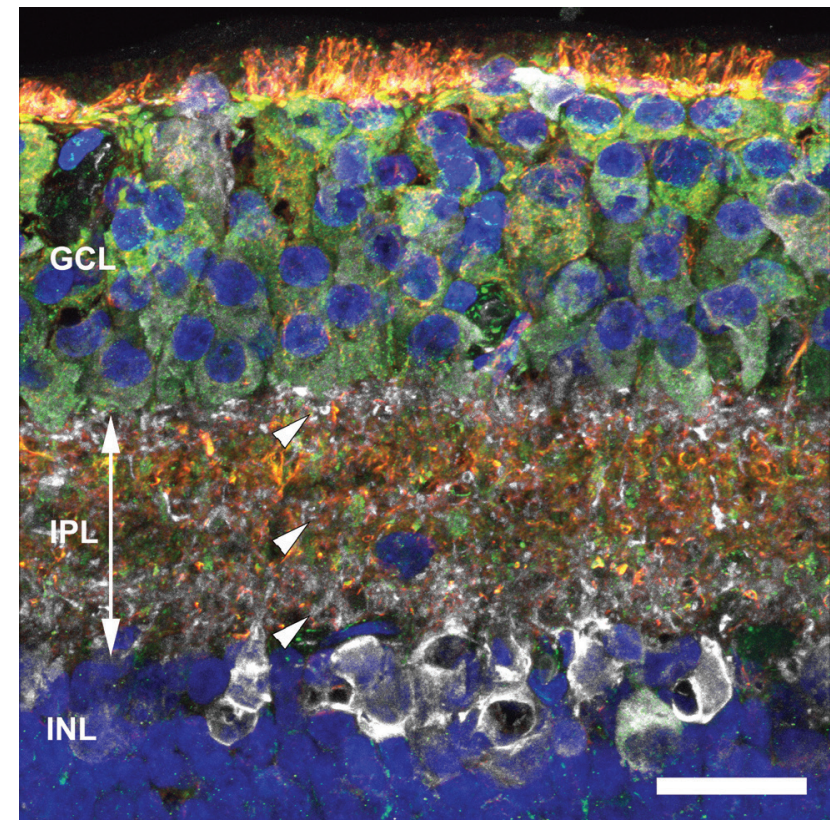

3. ábra $\mid$ Egészséges felnőtt emberi centrális belső retina konfokális mikroszkópos felvétele. A stratum ganglionare (GCL) ganglionsejtjei zöld színben (anti-RBPMS), a stratum granulosum internum amakrin sejtjei pedig szürke színben (antikalretinin) láthatók. A neurofilamentumok (anti-SMI32) vörös színnel, a sejtmagok kék színnel (DAPI) jelöltek. Jól megfigyelhetók a stratum plexiforme internum (IPL, kettốs nyíl) egymástól elkülönülő szinaptikus alrétegei (nyílhegyek). A lépték $25 \mu \mathrm{m}$. A munkacsoport korábban nem publikált felvétele

DAPI $=44^{\prime}, 6$-diamidino-2-fenilindol, egy fluoreszkáló folt; INL = belső magvas réteg 
and inner segments, OS and IS) a fotoreceptorok fényérzékeny kül- és organellumgazdag beltagjait tartalmazza (2. ábra). A kültagban a csapok esetében felületnövelő membránbefúződéseket találunk, míg a pálcikákban a felületnövelés membránkorongok segítségével jön létre. A fotoreceptorok membránja tartalmazza a fotopigmenteket. Ez utóbbiak az opszin nevű fehérjéből és 11 -ciszretinál prosztetikus csoportból épülnek fel, amely a látható tartományba eső fényinger hatására cisz-transz izomerizáción esik keresztül. A kültagot a beltaggal egy csilló köti össze. A beltag külső részét az ellipszoid adja, amely a fotorecepció energiaigényét fedező mitokondriumokat tartalmazza; belső részét a myoid alkotja, amely az opszin fehérje termeléséhez szükséges organellumokat foglalja magában. Az emberi retinában a duplicitási elv alapján kétféle fotoreceptor fordul elő: a pálcikák (coni) és a csapok (bacilli). A pácikák alacsony ingerküszöbü receptorok, és a fény kvantitatív érzékeléséért felelősek (scotopiás látás). A magas ingerküszöbű, színlátásért is felelős csapok hullámhossz-érzékenységük alapján három altípusra oszthatók. A csapok fényelnyelési maximumuknak megfelelően három csoportra oszthatók: kékérzékeny rövid ( $S$, „short”), zöldérzékeny közepes (M, „medium”) és vörösérzékeny hosszú (L, „long”) hullámhosszban található elnyelési maximummal rendelkező csapok. A csapok által közvetített részletgazdag látást photopicus látásnak nevezik [1-5].

A fotoreceptorok beltagja és sejtteste között a külsó határhártya (membrana limitans externa, outer limiting membrane, OLM) helyezkedik el, melyet a Müller-sejtek scleralis nyúlványai alkotnak, és zonula adherensek zárnak le. Ez a réteg lesz a külső és a belső retina határa, valamint ez a réteg felel meg az egykori ventriculus opticus felszínének. A fotoreceptorok perikaryonjai alkotják a külső magvas réteget (stratum granulosum externum, outer nuclear layer, ONL). A receptorok sejttesteiből az axonoknak megfelelő belső csap- és pálcikarostok indulnak ki, melyek a csapok esetében végtalpban (pediculus), a pálcikák esetében véggömbben végződnek (spherulum). Ezek a végződések szinaptizálnak a külső szinaptikus rétegben (stratum plexiforme externum, outer plexiform layer, OPL) a vertikális rendszer bipoláris és a laterális rendszer horizontális sejtjeivel. A horizontális gátló szinapszisok receptív mezők kialakulásával járnak, és megalapozzák a színdiszkriminációt és a kontrasztérzékelést. A belső magvas réteg (stratum granulosum internum, inner nuclear layer, INL) alapvetően négy sejttípus perikaryonját tartalmazza: a bipoláris, a horizontális, az amakrin és a Müller-sejtekét. A bipoláris sejtek a vertikális rendszerhez tartoznak, és szinapszisokat alkotnak a fotoreceptorokkal és a ganglionsejtekkel, a fotoreceptorok felől a ganglionsejtek felé továbbítva az ingert, így a látópálya második neuronját adják. Attól függően, hogy fényingerre vagy annak megszúnésekor aktiválódnak, elkülönítünk ON- és OFF-bipoláris sejteket. A törpe bipoláris sejtek egy fotoreceptorral, a diffúz bipoláris sejtek többel szinaptizálnak, az utóbbi esetben létrehoz- va a konvergencia jelenségét. A horizontális sejtek sejttestei a réteg scleralis, az amakrin sejtek sejttestei a réteg vitrealis oldalán helyezkednek el (3. ábra). A belső szinaptikus rétegben (stratum plexiforme internum, inner plexiform layer, IPL) találjuk a bipoláris sejtek ganglionsejtekkel alkotott szinapszisát, valamint az amakrin sejtek szinapszisait. Az amakrin sejtek axonnal nem rendelkeznek, és többféle neurotranszmitterrel (többek között GABA, glicin, dopamin vagy szerotonin) múködnek. A bipoláris sejtek a ganglion- és egyéb amakrin sejtekkel alkotnak jellemzően serkentő szinapszist, amelynek a horizontális jelfeldolgozásban van szerepe [1-5].

A ganglionsejtek rétegében (stratum ganglionare, ganglion cell layer, GCL) találjuk a látópálya harmadik neuronját (3. ábra). A ganglionsejt-populációk emberben még nem lettek karakterizálva; a diverzitást állatkísérletek kapcsán tudjuk megbecsülni, ennek megfelelően legalább harmincféle sejttípussal számolhatunk [6]. A ganglionsejtek dendritjei a bipoláris és az amakrin sejtekkel szinaptizálnak, míg axonjaik létrehozzák a nervus opticus, a chiasma opticum és a tractus opticus idegrostjait. A látópálya rostjainak legnagyobb része a corpus geniculatum lateraléban (CGL) végződik. A centrális retinától eltéróen a periférián a ganglionsejtek egy sorban helyezkednek el, és számos altípusuk ismert. A törpe ganglionsejtek egy bipoláris sejttel állnak kapcsolatban, és axonjaik a CGL parvocelluláris részébe konvergálnak; a napernyősejtek számos bipoláris és amakrin sejttel szinaptizálnak, és axonjaik a CGL magnocelluláris magjában végződnek. Újabb megfigyelések szerint a réteg idegsejtjeinek akár 30\%-át „eltévedt” („displaced”) amakrin sejtek alkotják [1]. A ganglionsejtek axonja, valamint az opticusrostok velóhüvelymentesek, és a vakfolt (papilla nervi optici) felé haladnak az opticusrostok rétegében (stratum neurofibrarum, nerve fibre layer, NFL). Ebben a rétegben (a belső retina többi rétegéhez hasonlóan) astrocytákat és microgliasejteket is találunk. Az IPL, a GCL és az NFL együttesen a ganglionsejtkomplexet (GCC) alkotják. Az opticusrostok myelinisatiója fejlődési rendellenesség, amely a fibrae medullares nevú elváltozást okozza. A rostokat az üvegtesttől a belső határhártya (membrana limitans interna, inner limiting membrane, ILM) választja el, amely a Müller-sejtek vitrealis nyúlványaiból és egy lamina basalisból áll. Ez a hártya biztosítja a retina mikrokörnyezetét, és megakadályozza a retinalis sejtek vándorlását az üvegtest felé [1-6].

\section{A retina sejtszintü vizsgálatának módszerei in vivo}

\section{Pásztázó lézeroftalmoszkópia (SLO)}

A retina sejtszintű leképzésében az első jelentős lépést Webb, Hughes és Pomerantzeff tette meg a pásztázó lézeroftalmoszkóp megalkotásával, amely radikálisan különbözött az addigi funduskamerák képalkotásától, 
azoknál lényegesen alacsonyabb fényexpozíciót alkalmazva. Az eszköz lényegében kitágított pupillán keresztül pontról pontra beszkenneli az ideghártyát. A konfokális SLO elve, hogy egy lézerforrás sugara a retinára vetül, a szöveten szórt fotonok egy része a detektorra jut, amely kiszúri a máshonnan érkező fénysugarakat. Egy fotoelektron-sokszorozó intenzifikáló hatásának segítségével detektálható jel keletkezik az alacsony intenzitás ellenére. Az eszköz axiális felbontása $300 \mu \mathrm{m}$, amely mai szemmel nézve csekély, azonban mérföldkövet jelentett a retina in vivo mikroszkópos képalkotásában. A modern eszközökben fényforrásként argonlézert, fotoelektron-sokszorozóként szilíciumdiódákat alkalmaznak.

A módszer továbbfejlesztett változata a pásztázó lézertomográfia, melyet a glaucoma diagnózisának megerősítésére és a látóidegfó állapotának megítélésére használnak. Alkalmas a beteg követésére és a progresszió monitorozására. Az eszköz SLO-mérések sorozatával kétdimenziós, több mélységben elkészített mérések segítségével háromdimenziós képet tud alkotni [7-10].

\section{Optikaikoherencia-tomográfia (OCT) és infravörös-spektroszkópia}

Az optikaikoherencia-tomográfia (OCT) olyan noninvazív módszer, mely lehetővé teszi az ideghártya nagy felbontású, keresztmetszeti leképezését. Az eljárás elvi szinten hasonlít az ultraszonográfiára, ebben az esetben azonban a fényforrás sugárzása a látható fényénél nagyobb hullámhosszú, a közeli infravörös tartományba esik (NIR, „near infrared”, $\lambda=800 \mathrm{~nm}-2,5 \mu \mathrm{m}$, OCT esetén jellemzően 850-1050 nm). A fényforrás után, a hagyományos diszperziós berendezésekkel ellentétben, nem monokromátor, hanem Michelson-féle interferométer helyezkedik el. Ez a monokromátorral ellentétben nem hullámhossztartományt, hanem hullámhosszsoro- zatot választ ki a fényút hosszának változtatásával az interferencia törvényeinek megfelelően. A módszer az interferometria elvén alapul, azaz a mintáról visszaverődött sugárzás interferál egy referenciasugárral. Az így kapott interferencia-mintázatot interferogramnak hívjuk, melyből Fourier-transzformáció segítségével kinyerhető az infravörös spektrum. A különböző sejtrétegek reflektivitása eltérő, ezáltal azok egymástól elkülöníthetők. Az ultrahanggal történő képalkotás analógiájára a visszaverő képességben mutatkozó eltéréseket leképező módszert A-szkennek, az ezek sorozatából létrehozott longitudinális felvételt B-szkennek nevezzük. Az OCT-vizsgálat előnye, hogy nonkontakt, és nincs szükség hozzá kapcsoló médiumra (például zselé) [8, 11-14].

A retina olyan háromdimenziós képlet, melynek vastagsága 100 és $400 \mu \mathrm{m}$ között változik, és az OCT áttörést jelentett az ideghártya transzverzális leképezésében. A berendezések fejlesztése ma is folyamatos, a különböző típusokat generációkba soroljuk: az első generációba a 'time-domain' (TD-OCT), a másodikba a 'Fourier-domain' (FD-OCT), a 'spectral-domain' (SS-OCD) és a 'swept-source' OCT (SS-OCT) tartozik. Az SD-OCT továbbfejlesztésével készült el az 'enhanced-depth imaging' OCT (EDI-OCT), amely az előbbi módszert kiegészítve ad lehetőséget a chorioidea vizsgálatára. A generációk közötti lényeges különbség az axiális felbontás javulása, amely a kezdeti 10-15 $\mu \mathrm{m}$-ról nagyjából $3 \mu \mathrm{m}$ re növekedett. Az OCT-B-szkenek sorozatos elkészítése után számítógépes feldolgozással létrehozható az ún. en face OCT-kép, avagy C-szken, amely a retina egy téglatest alakú részét ábrázolja három dimenzióban [12, 13$]$.

Az OCT-B-szken szürkeárnyalatos kétdimenziós harántképet ad a retináról, melyen egyes sejtrétegek világosan (hiperreflektív), más rétegek sötéten (hiporeflektív) jelennek meg fekete alapú kép esetén. A B-szken az eszköz beállításainak megfelelően fekete vagy fehér alapú

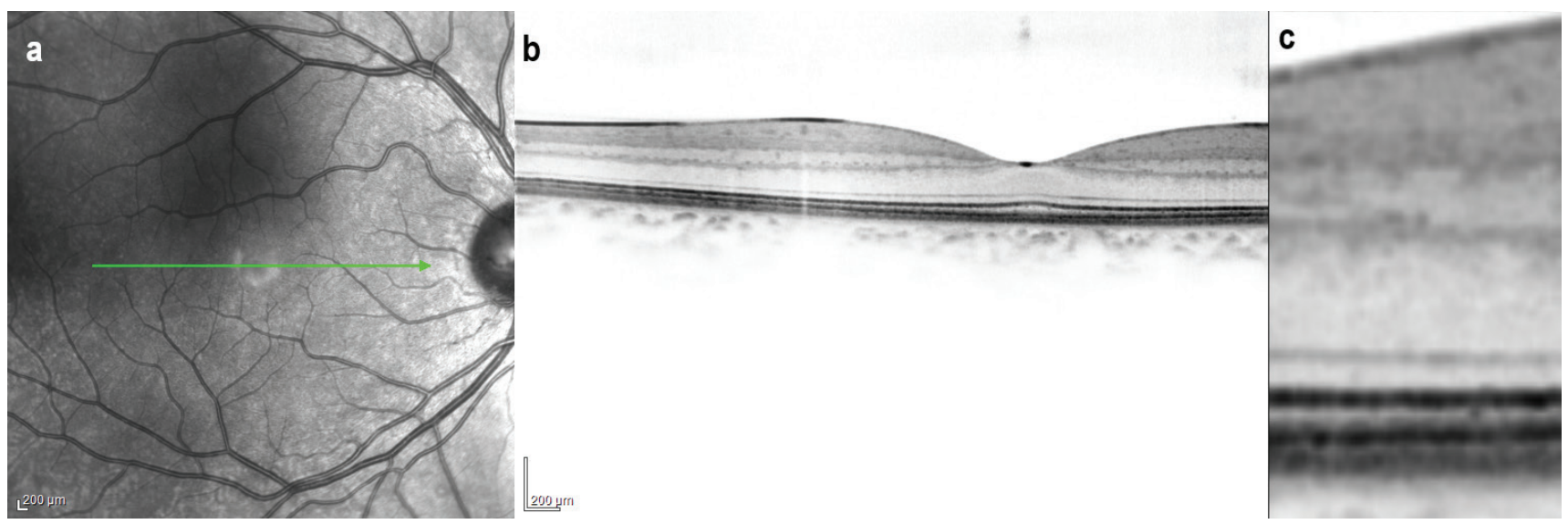

4. ábra

a) Egészséges fiatal felnőtt férfi jobb oldali fundusképe, a b) ábrán látható harántmetszet pozíciója világoszöld nyíllal jelölve. b) Az ép retina szürke árnyalatos fehér alapú transzverzális OCT-képe a fovea centralissal. A felvételek Heidelberg Spectralis OCT-készülékkel készültek. A lépték 200 um. c) Nagyított terület a b) ábráról, melyen megfigyelhetók a retina rétegei. Az üvegtesti irány az ábrán felfelé, az ínhártya iránya lefelé található. A rétegek ismertetését az 1. táblázat tartalmazza

OTC = optikaikoherencia-tomográfia 
szürkeárnyalatos képként jelenik meg, egyes eszközökön azonban hamis színes kép formájában is megjeleníthető. Az OCT-felvételek, illetve a szövettani metszetek struktúrája nagy hasonlóságot mutat, a különböző rétegek azonban nem feleltethetők meg egyértelmúen egymásnak (4. ábra). Az egyes rétegek megnevezését jelenleg a 2014-ben született nemzetközi klasszifikáció alapján határozzuk meg. Ez alapján 18 sávot különíthetünk el (1. táblázat). Az osztályozás helyességével kapcsolatban a mai napig kételyek merülnek fel, hiszen nem lehetünk biztosak abban, hogy az OCT-képen ábrázolódó sávok mely struktúráknak felelnek meg, különösen a külső retina területén $[8,11-14]$.

Az infravörös-spektroszkópia szempontjából a középinfravörös (MIR, „mid-infrared”, $\lambda=2,5-50 \mu \mathrm{m})$ tartomány (jellemzően $\lambda=3-30 \mu \mathrm{m}$ ) a leginkább hasznos, hiszen az ebbe a hullámhossztartományba eső sugárzás gerjeszti a molekulákat, azok ún. molekularezgéseit. Ezeknek a rezgéseknek a segítségével tudjuk azonosítani az egyes vegyületeket. A középinfravörös sugárzás tehát gerjeszti a molekulákat, azaz a gerjesztő foton rezgési frekvenciája és a gerjesztett molekula molekularezgése között rezonancia lép fel. Adott molekulát csak adott hullámhosszú sugárzás tud gerjeszteni. Az infravörös

1. táblázat |A retina rétegeinek nemzetközi konszenzuson alapuló OCTnevezéktana (Staurenghi [2014] alapján)

\begin{tabular}{|c|c|}
\hline Szerkezeti OCT & Anatómiai megfelelés \\
\hline 1. Hiperreflektív & Hátsó üvegtesti kéreg \\
\hline 2. Hiporeflektív & Praeretinalis ûr \\
\hline 3. Hiperreflektív & $\begin{array}{l}\text { Membrana limitans interna, stratum } \\
\text { neurofibrarum }\end{array}$ \\
\hline 4. Hiporeflektív & Stratum ganglionare \\
\hline 5. Hiperreflektív & Stratum plexiforme internum \\
\hline 6. Hiporeflektív & Stratum granulosum internum \\
\hline 7. Hiperreflektív & Stratum plexiforme externum \\
\hline 8. Hiporeflektív & $\begin{array}{l}\text { A sáv belső fele: Henle-réteg } \\
\text { A sáv külső fele: stratum granulosum } \\
\text { externum }\end{array}$ \\
\hline 9. Hiperreflektív & Membrana limitans externa \\
\hline 10. Hiporeflektív & Myoid zóna \\
\hline 11. Hiperreflektív & Ellipszoid zóna \\
\hline 12. Hiporeflektív & $\begin{array}{l}\text { Stratum neuroepitheliale } \\
\text { (fotoreceptorok kültagja) }\end{array}$ \\
\hline 13. Hiperreflektív & $\begin{array}{l}\text { A fotoreceptorok és a pigmenthám- } \\
\text { sejtek közötti interdigitáció zónája }\end{array}$ \\
\hline 14. Hiperreflektív & $\begin{array}{l}\text { Stratum pigmentosum és Bruch- } \\
\text { membrán komplex }\end{array}$ \\
\hline 15. Mérsékelten reflektív & Stratum choriocapillare (chorioidea) \\
\hline 16. Hiperreflektív & Sattler-réteg \\
\hline 17. Hiperreflektív & Haller-réteg \\
\hline $\begin{array}{l}\text { 18. Homogén, változó } \\
\text { reflektivitású }\end{array}$ & Chorioidea-sclera-kapcsolat \\
\hline
\end{tabular}

OCT = optikaikoherencia-tomográfia spektrumból több dologra is következtethetünk. A spektrum információt tartalmaz a vibráló csoport kémiai felépítéséről és a molekulában található szomszédos csoportok kémiai tulajdonságairól és redoxstatusáról. Az erre vonatkozó információkat az infravörös spektrumból nyerjük ki, melyet Fourier-transzformáció segítségével állítunk elő az interferogramból. A retina rétegeiben található sejtek biokémiai statusának leírására jelenleg állatkísérletek zajlanak az infravörös-spektroszkópia segítségével, melyben a biológiai minta $\lambda=2,5-10 \mu \mathrm{m}$ hullámhosszú sugárzással reagál. Ez a módszer nem destruálja az ideghártya sejtjeit, azonban adatokat szolgáltat azok metabolizmusáról, amely az egyes sejtekben jellegzetes elváltozásokat mutat bizonyos kórképekben a pigmenthámtól a ganglionsejtekig. A módszer alacsony szöveti penetrációval rendelkezik (néhány $\mu \mathrm{m}$ ), jelenleg ex vivo állatkísérletekben vizsgálják $[15,16]$.

\section{OCT-angiográfia (OCTA) és velocimetria}

Az OCT-angiográfia olyan noninvazív módszer, melynek segítségével három dimenzióban tudjuk ábrázolni a retina és a chorioidea vasculaturáját. Ez a vér alakos elemeirôl visszaverődő infravörös fény intenzitásának detektálásával érhető el [17, 18].

Az ideghártya vérellátását az arteria carotis internából eredő arteria ophthalmica adja. A külső retina avascularis, a lamina limitans externától scleralis irányba eső sejtek a chorioidea choriocapillaris rétegének ereiből táplálkoznak diffúzió és más transzportfolyamatok révén; a belső retina rétegei az arteria centralis retinae felől kapják vérellátásukat. A jelenleg forgalomban lévő készülékekkel jellemzően négy vascularis zónát tudunk elkülöníteni: 1) a stratum ganglionaréban található felszínes vascularis plexust; 2) a stratum plexiforme internum és externum közé eső mély vascularis plexust; 3 ) a külső retina avascularis zónáját, valamint a 4) chorioidea stratum choriocapillaréját. A módszerrel vizsgálható az adott érhálózat alakja és lefutása (szabályos vagy szabálytalan), átmérője (szúk vagy tág), és kinyerhetők egyéb biometrikus adatai. Neovascularisatio esetén természetesen ezek mellett új, patológiás vascularis zónák is megjelenhetnek, fóleg a vitreoretinalis határon vagy a fovea normálisan avascularis területén. OCTA segítségével a vascularis plexusokat három dimenzióban tudjuk vizsgálni en face képalkotás segítségével, amely igen hasznos a neovascularisatióval járó betegségekben, csakúgy, mint diabeteses retinopathiában és az időskori maculadegeneratio (AMD) exsudativ eseteiben. Vénás okklúzió és macularis teleangiectasia esetén az erek abnormalitásait figyelhetjük meg. Az OCTA felhasználási területe átfed az invazív festékbeadást igénylő fluoreszcens angiográfia (FLAG) és az indocianinzöld-angiográfia (ICGA) módszereivel, ezekkel ellentétben viszont noninvazív és nonkontakt. Emellett az OCTA háromdimenziós, a FLAG és az ICGA kétdimenziós képet ad a vizsgált erekról. Ugyanakkor, mivel csak a vér alakos elemeit képes megjeleníte- 
ni és a vérplazmát nem, nem alkalmas olyan jelenségek ábrázolására, mint a szivárgás („leakage”) és a pangás („pooling”), melyek szivárgó vérzések és mikroaneurizmák kimutatását segítenék. Ezen jelenségeket a FLAG és az ICGA képes ábrázolni. Az OCTA és a FLAG képes ábrázolni az ereket, és árulkodik azok biometrikus paramétereiről, a keringés sebességéről azonban nem nyilatkozik. Ennek kiküszöbölésére alkották meg a közeli infravörös sugárzással a Doppler-effektus elvén múködő OCT-velocimetriát, más néven kvantitatív OCTA-t. Az OCTA jelenleg terjed el a klinikumban a vasculatura kvalitatív elemzésére, ám a kvantitatív velocimetriai vizsgálatok még nem jelentek meg a mindennapi gyakorlatban. A retinalis keringés statikus és dinamikus hemodinamikai elemzése a jövőben több kórkép követésében is segítséget nyújthat, például glaucomában, diabeteses retinopathiában és az AMD nonexsudativ formájában, amelynél a vérkeringés sebessége jellemzően csökkent [13, 17-22].

\section{Fluoreszcencia-életidōs képalkotó oftalmoszkópia (FLIO)}

A FLAG során exogén fluorofórt viszünk be a szervezetbe, melynek eloszlását a vérplazmában detektáljuk. A szervezetben vannak azonban endogén fluorofórok is, melyek gerjesztés hatására jellemzően a látható fény tartományában emittálnak. Ez a fotofluoreszcencia jelensége. A retinában található fluorofórok megvilágítás hatására fotonokat emittálnak, a jelenséget fundus-autofluoreszcenciának nevezzük (FAF). A fluorofórokat egymástól az életidejük alapján különítjük el, melynek előnye, hogy jellemző a molekulára, és nem függ annak mennyiségétől. Ez az eljárás a FLIO. A fluorofórok egymással kölcsönhatásba léphetnek a Förster-típusú energiatranszfer (FRET) révén, melynek felismerése mérföldkő volt az eredmények értékelésében. Az emberi ideghártya in vivo számos fluorofórt tartalmaz. A leginkább ismert talán a pigmenthámsejtekben található lipofukszin, amely a sejtekben az öregedéssel párhuzamosan halmozódik fel, fototoxikus hatásokra és degenerációs folyamatokban a mennyisége megnő. Elnyelési maximuma 340-395 nm, emissziós maximuma 430-460nm és 540-640 nm. Az egészséges maculában található, antioxidáns hatású fluorofórokat macularis pigmentnek (MP) nevezzük; közéjük a lutein, a zeaxantin és a mezozeaxantin tartozik. Főleg a Müller-sejtekben és a Henle-rétegben helyezkednek el; elnyelési maximumuk nagyjából 460 nm, ezáltal megvédik a fotoreceptorokat a kék fény toxicitásától, valamint semlegesítik a reaktívoxigén-származékokat (ROS). A fluoreszcencia-életidő a szövet redoxállapotáról is árulkodik, hiszen a redukáló ekvivalensek $[\mathrm{NAD}(\mathrm{P}) \mathrm{H}, \mathrm{FAD}, \mathrm{FMN}]$ is fluorofórok. A nikotinamidok elnyelési maximuma nagyjából 350 nm, a flavinoidoké $450 \mathrm{~nm}$. Az extracelluláris mátrix komponensei közül egyes kollagének (I-IV. típus) és az elasztin képesek autofluoreszcenciára. A pigmentek közül a melanint és a bilirubint; az aromás aminosavak közül a fenilalanint, a tirozint és a triptofánt; a porfirinek közül a protoporfirin IX-et érdemes megemlíteni fluorofórként, melyek a retinában előfordulhatnak. A patológiás fluorofórok közül a késôi glikációs végtermékek (AGE-k) játszanak nagy szerepet, melyek mennyisége diabetes mellitusban szaporodik fel. FLIO során a fundus egy $30^{\circ}$-os területét vizsgáljuk, melynek központjában a macula helyezkedik el. Egészségesekben a legalacsonyabb életidőket a foveában detektáljuk. AMD-ben a pigmenthámon jellegzetes hipo- és hiperpigmentált területek jönnek létre, jellegzetes bisretinoid pigmentdepozitumok, drusenek keletkeznek. A pigmenthám lipofukszint halmoz fel, a Bruchmembrán mentén kötőszöveti rostok rakódnak le. Az elváltozások megváltoztatják az egyes területeken mérhető fluoreszcencia-életidőt, valamint ennek eloszlását (geografikus atrophia [GA] nem exsudativ esetben). Diabeteses retinopathiában felszaporodnak az AGE-k, ami endotheldiszfunkcióval és a proteinkináz C (PKC)útvonal megzavarásával jár. A glikációs termékek hatására a fluoreszcencia-életidő a vizsgált területen megnyúlik, amit részben a redukáló ekvivalensek mennyiségének csökkenése is okoz. Artériás elzáródása esetén a hipoperfundált retinaterületnek megfelelően hipofluoreszcens területet figyelhetünk meg. A FLIO egyes örökletes dystrophiák (retinitis pigmentosa, chorioideremia, Stargardt-betegség) diagnózisára és követésére is alkalmas a korábbi megfontolásoknak megfelelően. A neurodegeneratív betegségek közül Alzheimer-kórban a liquorban felszaporodó béta-amiloidok és tau-proteinek a retinában is (jellemzően a ganglionsejtek rétegében) lerakódnak, a jövőben így a fluoreszcens funduskép hozzájárulhat a betegség korai diagnózisához és a progresszió monitorozásához [23-26].

\section{Adaptiv optika ( $A O)$}

A funduskamerák laterális felbontása erősen korlátozott a szem optikai minősége által. Ennek fó tényezői az egészséges bulbus esetén is előforduló aberrációk és a pupilla átmérője. A felbontást a pupilla tágításával, ezáltal a numerikus apertúra befolyásolásával növelhetjük, ennek azonban értelemszerúen anatómiai korlátai vannak. A természetesen előforduló asztigmatizmust, mely monokromatikus aberrációkat hoz létre, a különböző törőközegek - például könnyfilm, szaruhártya, lencse szabálytalansága okozza, mely képletek jelentős egyéni variációt mutatnak a populációban. Az AO-rendszerek az aberrációkból adódó fényszóródás detektálásán, feldolgozásán, valamint hullámfront-analízisén és -korrekcióján keresztül alkalmasak azok kiküszöbölésére és igen jó (sejtszintű, akár szubcelluláris) felbontású kép alkotására. Az AO-t a már ismertetett módszerekkel kombinálhatjuk, így az AOSLO alkalmas többek között a fotoreceptorok számának és eloszlási geometriájának megítélésére, vizsgálhatók a ganglionsejtek és az opticusrostok, valamint a retinalis érhálózat. Ez azért fontos, mert az ideghártya neuron- és gliasejtjei átlátszóak, kon- 
vencionális módszerekkel nem vizualizálhatók. Hasonlóan, az OCT is kibővíthető AO-val, létrehozva az AO-OCT módszerét. A retinalis vasculopathiák vizsgálatára jelenleg fejlesztés alatt áll az AOSLO fluoreszcens angiográfia (AOSLO-FLAG), mellyel szubklinikai elváltozásokat is kimutathatunk például diabeteses retinopathiában vagy sarlósejtes anaemiában. Az AO egyelöre nem terjedt el a klinikumban [8, 24, 27-31].

\section{Kétfoton-fluoreszcenciás pásztázó lézeroftalmoszkópia (TPF-AOSLO)}

A kétfoton-excitációs (TPE) fluoreszcens képalkotás a jövőben igen hasznos lehet a szemészetben, hiszen mély penetrációra, háromdimenziós és szubcelluláris képalkotásra képes. A módszert az AO alapozta meg, melynek teljes neve adaptív optikai kétfoton-fluoreszcenciás pásztázó lézeroftalmoszkópia (TPF-AOSLO). A módszer a fotolumineszcencia, azon belül a fluoreszcencia elvén nyugszik. Az IR fotonok az egyes neuronok sejttestében található reporter molekulákat gerjesztik. TPE esetén egy molekulát két IR foton $(\lambda=730-920 \mathrm{~nm})$ gerjeszt. Az egyes sejtek aktivációját fluoreszcens jelzőmolekulákkal követhetjük nyomon. Az endogén fluorofórok közé többek közt redukáló ekvivalensek [NAD $(\mathrm{P}) \mathrm{H}, \mathrm{FAD}$ ], kötőszöveti rostok (kollagén, elasztin) és pigmentek (lipofukszin) tartoznak. Ezáltal elkülöníthetővé válhatnak például az egyes fotoreceptorok (csapok és pálcikák); a módszer lehetőséget nyithat egyes betegségek longitudinális követésére, például az opticus-neuropathiákéra, melyekben a retina kimeneti sejtjei, a ganglionsejtek pusztulnak. A TPE-képalkotást ex vivo tesztelték korábban; jelenleg állatkísérletek zajlanak a módszerrel kapcsolatban, melynek a klinikumban a ganglionsejt-veszteséggel járó betegségek (például glaucoma) diagnózisában és nyomon követésében lehet később fontos szerepe. Emellett vizsgálják szerepét az egyéb neuronok (például a bipoláris sejtek), a gliasejtek (például Müller-sejtek és astrocyták), a pericyták (általuk a kapillárisok), a fotoreceptorok és a pigmenthámsejtek leképezésében [32-37].

\section{A retina sejtszintü vizsgálatának ex vivo és in vitro módszerei}

$\mathrm{Az}$ emberi retina felépítését a következő ex vivo és in vitro módszerekkel tanulmányozhatjuk.

\section{Klinikai vagy post mortem akut szövet feldolgozása}

Az emberi retina részletes szövettani felépítéséről való ismereteink túlnyomórészt post mortem fixált vagy mütétek során eltávolított patológiás szövetek vizsgálatából származnak. Bár a post mortem minták elméletileg nagy számban hozzáférhetők a kutatók számára, a szövetek minősége jellemzően alacsony a halál beállta és a minta- vétel között eltelt többórás késés következtében. A klinikailag enukleált bulbusok felhasználhatósága pedig a szem eltávolítását szükségessé tevő elváltozás miatt korlátozott. A szerzők tapasztalata szerint a kutatás számára széles körben, akár funkcionális vizsgálatokra is alkalmas szövet kizárólag megfelelően menedzselt 'multiorgan' szervdonáció során gyưjthető $[4,38-40]$.

\section{Túlélö tenyészet}

Újabb felfedezés, hogy a szervdonációk során nyert, a keringés leálltát követő legrövidebb időn belül kinyert post mortem retina megfelelő környezetben az eredeti háromdimenziós szöveti szerkezetét megtartva, ún. organotipikus szövettenyészetként több hónapon át életben tartható [41]. A kis fokú degeneráció mellett a retina szerkezete intakt, sejtjei pedig vizsgálhatók maradnak akár 12 héten keresztül. Az eljárás többek között bizonyítottan alkalmas génterápiás eljárások fejlesztésére és tesztelésére, valamint retinabetegségek modellezésére is, melyek a retina in vivo, klinikai leképezését szolgáló múszerek és eljárások fejlesztésekor is haszonnal szolgálhatnak $[42,43]$.

\section{Organoid}

Több szervhez hasonlóan a retina vizsgálatában is eddig elképzelhetetlen lehetőséget teremt az ún. organoid technológia, mellyel felnőtt egyének véréből vagy kötőszövetes sejtjeiből hozható létre az eredetivel lényegében megegyező szövet. Az eljárás során donor már differenciált perifériás sejtjeit juttatják vissza indukált pluripotens őssejti állapotba, amelyekből ex vivo, a testen kívül növeszthetô a donor geno- és fenotípusát hordozó retinaszövet. Mivel a módszer genetikailag meghatározott retinabetegségben szenvedő emberek sejtjein is alkalmazható, segítségével az adott betegség modelljéül szolgáló patológiás retinaszövet is növeszthető, melyen a betegség a folyamatában is vizsgálható lehet $[4,44]$.

\section{Következtetés}

A retina sejtszintü képalkotásának módszerei részben ma már elérhetők a klinikumban. A SLO megjelenése után 40 évvel az OCT széles körben alkalmazott technika az ideghártya vizsgálatára; az OCTA is rendszeresen megjelenik a gyakorlatban, a kvantitatív velocimetriai mérések azonban a rutinvizsgálatok között még nem terjedtek el. Az OCT által nyújtott strukturális információ nélkülözhetetlen a gyakorló szemész számára. Bár a jobb felbontású eszközökkel egyre jobb lehetőség adódik a fotoreceptorok kül- és beltagjainak megítélésére, ami elengedhetetlen a csapokat és/vagy pálcikákat érintő retinadystrophiák felismerésében és követésében, a klinikai gyakorlatba bevezetett eszközök felbontása még mindig a klasszikus mikroszkópiával elérhető szint alatt marad. 
Az OCT a ganglionsejteket érintő betegségek, így a glaucoma progressziójának nyomon követésében is rendkívül informatív eszköz. Segítségével ma már rutinszerúen megítélhető a ganglionsejtek sürüsége, valamint a ganglionsejtek axonjait tartalmazó opticusrostok rétegének vastagsága is, ugyanakkor az eljárás nem ad információt a betegségekben érintett idegsejtek és gliasejtek pontos típusáról. Mivel az emberi retina sejtjeinek egyes altípusai részleteikben ismeretlenek, a múszerek feloldóképességének javulása csak a retina sejtpopulációinak egyidejú kísérletes molekuláris és morfológiai feltérképezése mellett vezethet jelentős, új diagnosztikai és terápiás konzekvenciákkal együtt járó eredményre.

A klinikumban szintén alkalmazott módszer napjainkban a FAF vizsgálata, amely az ideghártya sejtcsoportjainak anyagcsere-eltéréseit indikálja, melyek patognomikusak lehetnek egyes kórképekben.

Bár egyelőre a rutin szemészeti eszköztárba már bekerült képalkotó technológiák egyike sem éri el az ex vivo eljárásokkal nyerhető celluláris és szubcelluláris felbontást, fontos állatkísérletek és preklinikai vizsgálatok folynak olyan módszerekkel kapcsolatban, amelyek ezt a problémát áthidalhatják. Ezen ígéretes módszerek közé tartozik a szemaberrációt kiküszöbölő és a műszerek jobb illeszthetőségét lehetővé tevő $\mathrm{AO}$, a kétfoton-oftalmoszkópia és a FLIO. Ezen módszerek a szövettani szintü felbontás mellett az egyes sejtek metabolikus állapotáról adhatnak in vivo és valós idejü funkcionális információkat, melyeket az OCT által nyújtott strukturális adatokkal együtt kezelve még pontosabb képet kaphatunk pácienseink állapotáról és a terápia hatékonyságáról. Az új, nagy felbontású múszerek kifejlesztése multidiszciplináris, mások mellett orvosokat, biológusokat, mérnököket, fizikusokat is magukban foglaló teamek közös erőfeszítése révén valósulhat meg.

Az új technikák kidolgozása mellett feltétlenül szükséges az emberi retina múködésének és felépítésének alaposabb megismerése is. A fejlesztések során az emberi szövet nem helyettesíthető teljesen állati eredetű, akár fóemlősszövetekkel; így az emberi szemre adaptált klinikai képalkotó módszerek létrehozásához is humán eredetű modellrendszerekre, valamint az emberi retina felépítésének és múködésének sejtszintü megismerésére van szükség.

Anyagi támogatás: A kézirat a Felsőoktatási Intézményi Kiválósági Program Neurológia tématerületi támogatásával jött létre.

Szerzői munkamegosztás: V. A.: A kézirat koncepciójának összeállítása és a kézirat megírása. M. D. P., K. F.: Az 1-3. ábrák és az ezekhez használt szövettani preparátumok elkészítése. Cs. A.: A kézirat megírása, szakmai szupervízió. R. M.: Szakmai szupervízió, a 4. ábrához használt OCT-felvétel elkészítése. N. Z. Zs.: Szakmai szupervízió. Sz. A.: A kézirat koncepciójának összeállítása és a kézirat megírása, szakmai szupervízió.

Érdekeltségek: A szerzőknek nincsenek érdekeltségeik.

\section{Köszönetnyilvánítás}

Köszönjük a Felsőoktatási Intézményi Kiválósági Program Neurológia tématerületi támogatását.

\section{Irodalom}

[1] Szabó A. The anatomy of the healthy retina. In: Récsán Zs, Nagy ZZs. (eds.) Optical coherence tomography in ophthalmology. [Az ép ideghártya anatómiája. In: Récsán Zs, Nagy ZZs. (szerk.) Optikai koherencia tomográfia a szemészetben.] Semmelweis Kiadó, Budapest, 2018; pp. 49-52. [Hungarian]

[2] Szél Á. Retina. In: Röhlich P. (ed.) Histology. [Belső burok vagy ideghártya (retina). In: Röhlich P. (szerk.) Szövettan.] Semmelweis Kiadó, Budapest, 2014; pp. 493-502. [Hungarian]

[3] Hoon M, Okawa H, Della Santina L, et al. Functional architecture of the retina: development and disease. Prog Retin Eye Res. 2014; 42: 44-84.

[4] Cowan CS, Renner M, De Gennaro M, et al. Cell types of the human retina and its organoids at single-cell resolution. Cell 2020; 182: 1623-1640.e34.

[5] Peng YR, Shekhar K, Yan W, et al. Molecular classification and comparative taxonomics of foveal and peripheral cells in primate retina. Cell 2019; 176: 1222-1237.e22.

[6] Baden T, Berens P, Franke K, et al. The functional diversity of retinal ganglion cells in the mouse. Nature 2016; 529: 345-350.

[7] Fischer J, Otto T, Delori F, et al. Scanning laser ophthalmoscopy (SLO). In: Bille JF. (ed.) High resolution imaging in microscopy and ophthalmology: new frontiers in biomedical optics. Chapter 2. Springer, Cham, 2019; pp. 35-57.

[8] Williams DR. Imaging single cells in the living retina. Vision Res. 2011; 51: 1379-1396.

[9] Webb RH, Hughes GW, Pomerantzeff O. Flying spot TV oph thalmoscope. Appl Opt. 1980; 19: 2991-2997.

[10] Chauhan BC, Blanchard JW, Hamilton DC, et al. Technique for detecting serial topographic changes in the optic disc and peripapillary retina using scanning laser tomography. Invest Ophthalmol Vis Sci. 2000; 41: 775-782.

[11] Aumann S, Donner S, Fischer J, et al. Optical coherence tomog raphy $(\mathrm{OCT})$ : principle and technical realization. In: Bille JF. (ed.) High resolution imaging in microscopy and ophthalmology: new frontiers in biomedical optics. Chapter 3. Springer, Cham, 2019; pp. 59-85.

[12] Schneider M. The theoretical basis of the optical coherence tomography. In: Récsán Zs, Nagy ZZs. (eds.) Optical coherence tomography in ophthalmology. [Az optikai koherencia tomográfia elvi alapjai. In: Récsán Zs, Nagy ZZs. (szerk.) Optikai koherencia tomográfia a szemészetben.] Semmelweis Kiadó, Budapest, 2018; pp. 7-16. [Hungarian]

[13] Récsán Zs. The interpretation of the structural and angigraphy OCT of the healthy retina and choroidea. In: Récsán Z, Nagy ZZs. (ed.) Optical coherence tomography in ophthalmology. [Az ép ideg- és érhártya szerkezeti és angiográfiás OCT leképezésének értelmezése. In: Récsán Zs, Nagy ZZs. (szerk.) Optikai koherencia tomográfia a szemészetben.] Semmelweis Kiadó, Budapest, 2018; pp. 53-59. [Hungarian]

[14] Cuenca N, Ortuño-Lizarán I, Pinalla I. Cellular characterization of OCT and outer retinal bands using specific immunohisto- 
chemistry markers and clinical implications. Ophthalmology 2018; 125: 407-422.

[15] Aboualizadeh E, Hirschmugl CJ. Highlighting IR spectrochemical imaging of the retina. Trends Biochem Sci. 2018; 43: 650653.

[16] Barth A. Infrared spectroscopy of proteins. Biochim Biophys Acta 2007; 1767: 1073-1101.

[17] Rocholz R, Corvi F, Weichsel J, et al. OCT angiography (OCTA) in retinal diagnostics. In: Bille JF. (ed.) High resolution imaging in microscopy and ophthalmology: new frontiers in biomedical optics. Chapter 6. Springer, Cham, 2019; pp. 135-160.

[18] Hirano T, Chanwimol K, Weichsel J, et al. Distinct retinal capillary plexuses in normal eyes as observed in optical coherence tomography angiography axial profile analysis. Sci Rep. 2018; 8: 9380.

[19] Spaide RF, Fujimoto JG, Waheed NK, et al. Optical coherence tomography angiography. Prog Retin Eye Res. 2018; 64: 1-55.

[20] Braaf B, Gräfe MGO, Uribe-Patarroyo N, et al. OCT-based velocimetry for blood flow quantification. In: Bille JF. (ed.) High resolution imaging in microscopy and ophthalmology: new frontiers in biomedical optics. Chapter 7. Springer, Cham, 2019; pp. 161-179.

[21] Chu Z, Lin J, Gao C, et al. Quantitative assessment of the retinal microvasculature using optical coherence tomography angiography. J Biomed Opt. 2016; 21: 66008.

[22] Jia Y, Bailey ST, Hwang TS, et al. Quantitative optical coherence tomography angiography of vascular abnormalities in the living human eye. Proc Natl Acad Sci USA 2015; 112: E2395-E2402.

[23] Bernstein P, Dysli C, Fischer J, et al. Fluorescence lifetime imaging ophthalmoscopy (FLIO). In: Bille JF. (ed.) High resolution imaging in microscopy and ophthalmology: new frontiers in biomedical optics. Chapter 10. Springer, Cham, 2019; pp. 213235 .

[24] Li DQ, Choudhry N. The future of retinal imaging. Curr Opin Ophthalmol. 2020; 31: 199-206.

[25] Sauer L, Andersen KM, Dysli C, et al. Review of clinical approaches in fluorescence lifetime imaging ophthalmoscopy. J Biomed Opt. 2018; 23: 1-20. [Erratum: J Biomed Opt. 2018; 23: 1.]

[26] Dysli C, Wolf S, Berezin MY, et al. Fluorescence lifetime imaging ophthalmoscopy. Prog Retin Eye Res. 2017; 60: 120-143.

[27] Burns SA, Elsner AE, Sapoznik KA, et al. Adaptive optics imaging of the human retina. Prog Retin Eye Res. 2019; 68: 1-30.

[28] Harmening WM, Sincich LC. Adaptive optics for photoreceptortargeted psychophysics. In: Bille JF. (ed.) High resolution imaging in microscopy and ophthalmology: new frontiers in biomedical optics. Chapter 17. Springer, Cham, 2019; pp. 359-375.

[29] Jayabalan GS, Kessler R, Fischer J, et al. Compact adaptive optics scanning laser ophthalmoscope with phase plates. In: Bille JF. (ed.) High resolution imaging in microscopy and ophthalmology: new frontiers in biomedical optics. Chapter 18. Springer, Cham, 2019; pp. 376-394.
[30] Liu Z, Kurokawa K, Zhang F, et al. Imaging and quantifying ganglion cells and other transparent neurons in the living human retina. Proc Natl Acad Sci USA 2017; 114: 12803-12808.

[31] Rossi EA, Granger CE, Sharma R, et al. Imaging individual neurons in the retinal ganglion cell layer of the living eye. Proc Natl Acad Sci USA 2017; 114: 586-591.

[32] Kamali T, Farrell SRM, Baldridge WH, et al. Two-photon scanning laser ophthalmoscope. In: Bille JF. (ed.) High resolution imaging in microscopy and ophthalmology: new frontiers in biomedical optics. Chapter 9. Springer, Cham, 2019; pp. 195-211.

[33] Sharma R, Yin L, Geng Y, et al. In vivo two-photon imaging of the mouse retina. Biomed Opt Express 2013; 4: 1285-1293.

[34] Sharma R, Williams DR, Palczewska G, et al. Two-photon autofluorescence imaging reveals cellular structures throughout the retina of the living primate eye. Invest Ophthalmol Vis Sci. 2016; 57: 632-646.

[35] Kusnyerik A, Rózsa B, Veress M, et al. Modeling of in vivo acousto-optic two-photon imaging of the retina in the human eye. Opt Express 2015; 23: 23436-23449.

[36] Carroll J, Kay DB, Scoles D, et al. Adaptive optics retinal imaging - clinical opportunities and challenges. Curr Eye Res. 2013; 38: 709-721

[37] Morgan JI. The fundus photo has met its match: optical coherence tomography and adaptive optics ophthalmoscopy are here to stay. Ophthalmic Physiol Opt. 2016; 36: 218-239.

[38] Berta AI, Kiss AL, Kemény-Beke A, et al. Different caveolin isoforms in the retina of melanoma malignum affected human eye. Mol Vis. 2007; 13: 881-886.

[39] Kántor O, Mezey S, Adeghate J, et al. Calcium buffer proteins are specific markers of human retinal neurons. Cell Tissue Res. 2016; 365: 29-50

[40] Kántor O, Benkő Z, Énzsöly A, et al. Characterization of connexin36 gap junctions in the human outer retina. Brain Struct Funct. 2016; 221: 2963-2984.

[41] Szabo A, Kusnyerik Á, Kilin F, et al. Long-term organotypic co-culture model of the adult human retina, RPE and choroid. Invest Ophthalmol Vis Sci. 2018; 59: 4021.

[42] Jüttner J, Szabó A, Gross-Scherf B, et al. Targeting neuronal and glial cell types with synthetic promoter AAVs in mice, non-human primates and humans. Nat Neurosci. 2019; 22: 1345-1356.

[43] Nelidova D, Morikawa RK, Cowan CS, et al. Restoring light sensitivity using tunable near-infrared sensors. Science 2020;368: $1108-1113$.

[44] Eiraku M, Takata N, Ishibashi H, et al. Self-organizing optic-cup morphogenesis in three-dimensional culture. Nature 2011; 472: 51-56.

(Szabó Arnold dr., Budapest, Tüzoltó u. 58., 1094 e-mail: szabo.arnold@med.semmelweis-univ.hu)

A cikk a Creative Commons Attribution 4.0 International License (https://creativecommons.org/licenses/by/4.0/) feltételei szerint publikált Open Access közlemény, melynek szellemében a cikk bármilyen médiumban szabadon felhasználható, megosztható és újraközölhető, feltéve, hogy az eredeti szerző és a közlés helye, illetve a CC License linkje és az esetlegesen végrehajtott módosítások feltüntetésre kerülnek. (SID_1) 